\title{
Pengaruh Pembiayaan Modal Kerja Pemerintah terhadap Pendapatan Usaha Mikro Kerupuk Udang di Teluk Nilau Tanjung Jabung Barat
}

\author{
Ahmad Tarmizi \& Riski Adha \\ Fakultas Ekonomi dan Bisnis Islam UIN Sulthan Thaha Saifuddin Jambi
}

\begin{abstract}
Abstrak: Skripsi ini bertujuan untuk mengetahui bagaimana pengaruh pembiayaan modal kerja dari pemerintah dan profesionalisme sumber daya manusia terhadap naik atau tidaknya tingkat pendapatan masyarakat Teluk Nilau yang berprofesi sebagai pengrajin kerupuk udang. Melalui metode kuantitatif deskriptif, populasi penelitian ini adalah seluruh pengrajin kerupuk udang yang ada di Teluk Nilau. Hasil penelitian melalui uji $\mathrm{F}$ menunjukkan bahwa variabel pembiayaan modal kerja dari pemerintah (X1) dan profesionalisme (X2) secara bersama-sama memengaruhi tingkat pendapatan usaha (Y), pengaruh yang diberikan variabel X1 dan X2 terhadap variable Y sebesar 15,581\%, dan dari hasil uji T pembiayaan modal kerja dari pemerintah berpengaruh signifikan terhadap tingkat pendapatan usaha engan nilai $4,637 \%$ begitu pula dengan profesionalisme yang juga berpengaruh signifikan terhadap tingkat pendapatan usaha dengan nilai 3,018\%.

Kata-kata kunci: pembiayaan modal kerja; profesionalisme; tingkat pendapatan.
\end{abstract}

\section{Pendahuluan}

Perkembangan perekonomian saat ini telah mengalami peningkatan yang signifikan pada setiap tahunnya khususnya di provinsi jambi. Hal ini di dorong oleh pertumbuhan sektor-sektor perekonomian yaitu antara lain sektor pertanian, perbankan, dan industri. Salah satu pendorong lainnya adalah sektor industri dengan sub sektor UMKM (usaha mikro kecil dan menengah). Usaha mikro kecil dan menengah merupakan salah satu usaha penyangga utama yang dapat menyerap tenaga kerja. Usaha mikro, kecil dan menengah mempunyai peran yang strategis dalam pembangunan ekonomi nasional tidak hanya di negara-negara berkembang, tetapi juga di negara-negara maju. UMKM juga sangat berperan penting sebagai sumber pendapatan bagi kelompok miskin, distribusi pendapatan dan pengurangan kemiskinan, serta pembangunan ekonomi pedesaan. ${ }^{1}$

Perkembangan UMKM di provisi jambi sendiri tidak terlepas dari peran pemerintah yang selalu memberikan dukungan kepada masyarakat dalam mengembangkan usaha mikro kecil dan menengah yang dijalankannya dengan berbagai dukungan diantaranya adalah dengan diadakannya pelatihan dan dukungan fiansial (dana atau alat) oleh pemerintah. Selain hal tersebut UMKM di Jambi berkembang dengan adanya kemampuan dan sumber daya masyarakat yang dapat bersaing. Hal ini selaras dengan pernyataan Bayu Yuga Tahtakusuma dalam tulisannya mengatakan sumber daya manusia merupakan hal penting dalam suatu organisasi perusahaan, maka diperlukan suatu usaha utuk mengolah secara

\footnotetext{
${ }^{1}$ Arikunto. S, Prosedur Penelitian Suatu Pendekatan Praktik, Jakarta: Rineka Cipta, 2006.
} 
professional agar terwujud suatu keseimbangan antara kebutuhan agar tenaga kerja mau dan mampu memberikan prestasi kerjanya sebaik mungkin. Dalam hal tersebut perusahaan berkewajiban memperhatikan kebutuhan karyawannya baik yang bersifat materil maupun yang bersifat non materil.Wujud dari perhatian, usaha serta yang dapat dilakukan oleh perusahaan terhadap karyawannya, salah satunya adalah dengan melaksanakan promosi jabatan yang objektif dan adil serta penempatan yang tepat.

Peningkatan kualitas sumber daya manusia sangat diperlukan, hal ini juga sejalan dengan fakta-fakta yang dikemukakan pada jurnal manajemen dan kewirausahaan karangan I.D.K.R Ardiana dkk menyatakan bahwa pengembangan UMKM harus disertai dengan pengembangan SDM dalam berbagai aspek. Salah satu hasil survei menunjukkan bahwa tingkat pendidikan pengusaha UMKM di Indonesia adalah SLTA $(44,1 \%)$, D3 $(7,4 \%)$ dan S1 $(17,9 \%)$ dan sisanya dibawah SLTA. Fakta ini sebenarnya menepis pandangan bahwa pendidikan UMKM di Indonesia relatif rendah.Namun peningkatan kualitas SDM sangat diperlukan terutama di bidang kompetensi SDM seperti knowledge, skill dan ability serta attitude dalam berwirausaha. Pengembangan SDM harus dilakukan tidak hanya kepada UMKM sebagai pemilik usaha, tetapi juga para pekerjanya.Semangat kewirausahaan dan peningkatan produktivitas yang di dukung pengembangan teknologi menjadi penting dalam fokuf penguatan SDM. Di sisi lain, penggunaan teknologi mekin penting mengingat $60 \%$ proses produksi UMKM masih dilakukan secara sederhana.

Di provinsi jambi memiliki kekayaan alam yang sangat melimpah salah satunya adalah kekayaan laut. Dari berbagai kabupaten yang ada di provinsi Jambi dengan sejuta kekayaan yang ada di kabupaten-kabupaten tersebut. Salah satunya Kabupaten Tanjung Jabung Barat yang mempunyai kekayaan laut yang cukup melimpah, dengan kekayaan laut yang berlimpah masyarakat setempat bisa menciptakan sebuah produk kuliner (lebih menjurus ke kerupuk). Kuliner yang diciptakan oleh masyarakat adalah kerupuk yang berbahan baku udang, yang mulai marak di produksi masyarakat di tahun 2016, pengrajin kerupuk yang lebih banyak memproduksi kerupuk tersebut adalah di Kelurahan Teluk Nilau.

Permasalahan umum yang dihadapi para pengrajin umkm kerupuk ini di kelurahann teluk nilau adalah kurangnya modal. Dalam hal ini modal yang dimaksud adalah kurangnya alat-alat untuk mengolah kerupuk udang, dan kurangnya pelatihan untuk masyarakat setempat agar bisa memiliki kualitassumber daya manusia yang mempuni dan dapat bersaing dengan produkproduk yang dibuat dari wilayah atau daerah lain. Salah satu harapan masyarakat (pengrajin kerupuk udang) di kelurahan teluk nilau menginginkan partisipasi dari pemerintah baik dari segi pendanaan untuk menambah modal kerja, alat-alat untuk mempermudah dan mempercepat proses pembuatan kerupuk serta pelatihan kepada para pengrajin agar pengrajin bisa lebih profesional dari sebelumnya. 


\section{Pembiayaan Modal Kerja}

Pembiayaan atau financing adalah pendanaan yag diberikan oleh suatu pihak kepada pihak lain untuk mendukung investasi yang telah direncanakan, baik dilakukan sendiri maupun lembaga. Dengan kata lain, pembiayaan adalah pendanaan (dana, barang dan alat) yang dikeluarkan untuk mendukung investasi yang telah direncanakan. Pembiayaan modal kerja merupakan pembiayaan untuk kebutuhan peningkatan produksi baik secara kuantitatif (jumlah hasil produksi) maupun secara kualitatif (peningkatan kualitas mutu hasil produksi) dan untuk keperluan perdagangan atau peningkatan utility of place dari suatu barang.

Tujuan Pembiayaan Modal Kerja

Menurut Kasmir tujuan pembiayaan modal kerja terdiri dari tiga yaitu:

1. Pembiayaan konsumtif, bertujuan untuk memperoleh barang-barang atau kebutuhan-kebutuhan lainnya guna memenuhi keputusan dalam konsumsi.

2. Pembiayaan produktif, bertujuan untuk memungkinkan penerima pembiayaan dapat mencapai tujuannya yang apabila tanpa pembiayaan tersebut tidak mungkin dapat diwujudkan.

3. Pembiayaan perdagangan, pembiayaan ini digunakan untuk perdagangan, biasanya digunakan untuk membeli barang dagangan yang pembayarannya diharapkan dari hasil penjualan barang dagangan tersebut. ${ }^{2}$

\section{Faktor-Faktor yang Memengaruhi Modal Kerja}

Modal kerja menurut Sundjaja daan Barlian yaitu aktiva lancar yang mewakili bagian dari investasi yang berputar dari satu bentuk ke bentuk lainnya dalam melaksanakan suaatu usaha, atau modal kerja adalah kas/bank, surat-surat berharga yang mudah diuangkan (giro, cek dan deposito), piutang dagang dan persediaan yang tingkat perputarannya tidak melebihi satu tahun atau jangka waktu operasi normal perusahaan.

Profesionalisme ialah sifat-sifat (kemampuan, kemahiran, cara pelaksanaan sesuatu hal dan lain-lain). Sebagaimana yang sewajarnya terdapat pada atau dilakukan oleh orang professional.Profesionalisme berasal dari pada profesion yang bermakna, berhubungan dengan profesion dan memerulukan kepandaian khusus untuk menjalankannya, (KBBI). Jadi, profesionalisme adalah tingkah laku, kepakaran arau kualiti dari seseorang yang professional.

Menurut Prof. Edgar Shine professional adalah bekerja sepenuhnya (full time) berbeda dengan amatir yang sambilan, mempunyai pengetahuan (science) dan keterampilan (skill), membuat keputusan atas nama klien (pemberi tugas), berorientasi pada pelayanan (service orientation). Kendala atau permasalahan UMKM, yang dikutip dari kompasiana adalah kualitas sumber daya manusia UMKM yang masih rendah serta minimnya pengetahuan dan kompetensi kewirausahaan mengakibatkan rendahnya produktifitas usaha dan tenaga kerja. Hal tersebut juga tampak pada ketidak mampuan mereka dalam hal manajemen usaha, terutama dalam hal tata tertib pencatatan/pembukuan. ${ }^{3}$

\footnotetext{
${ }^{2}$ Kasmir, Analisis Laporan Keuangan, Jakarta: Raja grafindo Persada, 2012.

${ }^{3}$ Kasmir, Manajemen Sumber Daya Manusia (Teori Dan Praktik), Jakarta: Raja grafindo Persada 2016.
} 
Menurut Wilson Bangun, dalam bukunya manajemen sumber daya manusia. Manajemen sumber daya dalam menjalankan fungsinya akan mendistribusikan pekerja ke berbagai bidang dalam organisasi kebutuhannya. Ini menunjukkann bahwa bahwa manajemen sumber daya manusia mempunyai keterkaitan dengan manajemen bidang lain dalam organisasi untuk mencapai hasil kerja yang efektif. Tentu bidang-bidang lain akan membutuhkan pekerja yang berkualitas untuk dapat mempertahankan atau meningkatkan pelayanannya kepada masyarakat.

Dalam praktiknya tidak selamanya bahwa kinerja karyawan dalam kondisi seperti yang diinginkan baik oleh karyawan itu sendiri ataupun organisasi. Banyak kendala yang memengaruhi kinerja, baik kinerja organisasi maupun kierja individu.Ada baiknya seorang prmimpin harus mengkaji terlebih dahulu tentang faktor-faktor yang dapat memengaruhi kinerja karyawannya.Jadi atasan langsung sebagai penilai bawahannya harus menyadari adanya perbedaan kinerja antara karyawan yang berada di bawah pengawasannya. Sekalipun karyawan bekerja pada tempat yang sama, namun produktifitas mereka tidaklah selalu sama. Perbedaan ini akan mengakibatkan kinerja seseorang tidaklah sama.

Menurut pengertian akuntansi keuangan, pendapatan adalah peningkatan jumlah aktiva atau penurunan kewajiban suatu organisasi sebagai akibat dari penjualan barang dan jasa kepada pihak lain dalam periode tertentu. Sedangkan dalam kamus manajemen pendapatan adalah uang yang diterima oleh perorangan, perusahaan, organisasi lain dalam bentuk upah, gaji, sewa, komisi dan laba. ${ }^{4}$

Sukrisno mendefenisikan pendapatan adalah jumlah penghasilan yang diterima oleh penduduk atas prestasi kerjanya satu periode tertentu, baik harian, mingguan, bulanan ataupun tahunan. Dari pengertian diatas dapat disimpulkan bahwa tigkat pendapatan itu ialah naik atau tidaknya pendapatan seseorang atas pekerjaan yang telah dia lakukan baik bekerja dengan orang lain ataupun bekerja sendiri (wirausaha) dalam periode tertentu.

Ada beberapa faktor-faktor yang mempengaruhi pendapatan, yaitu:

1. Banyak sedikitnya modal yang digunakan.

Besar kecilnya usaha yang dilakukan seseorang sangat dipengaruhi oleh besar kecilnya modal yang dipergunakan. Suatu usaha yang besar akan dapat memberikan peluang yang besar pula terhadap pendapatan yang diperoleh.

2. Kesempatan kerja yang tersedia

Semakin banyak kesempatan kerja yang tersedia berarti semakin banyak penghasilan yang bisa diperoleh dari hasil kerja tersebut.

3. Kecakapan dan keahlian

Dengan bekal dan keahlian yang tinggi akan dapat meningkatkan pula efisiensi dan efektifitas yang pada akhirnya berpengaruh pula terhadap penghasilan.

4. Keuletan kerja

Keuletan kerja dapat diartikan dengan ketekunan, keberanian untuk menghadapi segala macam tantangan.Bila saat menghadapi kegagalan maka

${ }^{4}$ Danang Sunyoto, Metode Penelitian Akuntansi, Bandung: Refika Aditama, 2013. 
kegagalan tersebut dijadikan sebagai bekal untuk meneliti kesuksesan dan keberhasilan. ${ }^{5}$

Penelitian ini telah melakukan uji validitas untuk mengukur sah atau valid tidaknya suatu kuesioner. Suatu kuesioner dinyatakan sah atau valid jika pernyataan atau pertanyaan pada kuesioner tersebut mampu mengungkapkan suatu yang akan diukur oleh kuesioner itu. Bila korelasi tiap faktor tersebut positif dan besarnya 0,3 ke atas maka faktor tersebut merupakan construct yang kuat.

a. Pembiayaan Modal Kerja Dari Pemerintah

Tabel 1

Hasil Uji Validitas Pembiayaan Modal Kerja Dari Pemerintah (X1)

\begin{tabular}{|c|c|c|c|}
\hline Item pernyataan & R hitung & R minimum & Keterangan \\
\hline 1 & 0,314 & 0,3 & Valid \\
\hline 2 & 0,767 & 0,3 & Valid \\
\hline 3 & 0,545 & 0,3 & Valid \\
\hline 4 & 0,649 & 0,3 & Valid \\
\hline
\end{tabular}

Berdasarkan hasil pengujian pada tabel 4.5 dapat diketahui bahwa 4 item pernyataan variabel Pembiayaan modal kerja dari pemerintah memiliki $r$ hitung lebih besar dibandingkan $r$ minimum, maka seluruh item pernyataan dianggap valid dan dapat digunakan dalam penelitian.

b. Profesionalisme

Tabel 2

Profesionalisme (X2)

\begin{tabular}{|c|c|c|c|}
\hline Itam pernyataan & R hitung & R minimum & Keterangan \\
\hline 1 & 0,661 & 0,3 & Valid \\
\hline 2 & 0,685 & 0,3 & Valid \\
\hline 3 & 0,447 & 0,3 & Valid \\
\hline 4 & 0,390 & 0,3 & Valid \\
\hline 5 & 0,445 & 0,3 & Valid \\
\hline 6 & 0,368 & 0,3 & Valid \\
\hline
\end{tabular}

Berdasarkan hasil pengujian pada tabel 2 dapat diketahui bahwa 6 item pernyataan variabel Profesionalisme memiiki $r$ hitung lebih besar dibandingkan $r$ minimum, maka dapat disimpulkan seluruh item pernyataan dianggap valid dan dapat digunakan dalam penelitian.

\footnotetext{
${ }^{5}$ M. Fuad dkk, Pengantar Bisnis, Jakarta: Gramedia Pustaka Umum, 2006.
} 
c. Tingkat Pendapatan

Tabel 3

Tingkat Pendapatan Usaha (Y)

\begin{tabular}{|c|c|c|c|}
\hline Item pernyataan & R hitung & R minimum & Keterangan \\
\hline 1 & 0,751 & 0,3 & Valid \\
\hline 2 & 0,799 & 0,3 & Valid \\
\hline 3 & 0,827 & 0,3 & Valid \\
\hline
\end{tabular}

Berdasarkan hasil penelitian pada tabel 4.7 dapat diketahui bahwa 3 item pernyataan vriabel Tingkat Pendapatan memiliki $r$ hitung lebih besar dari $r$ minimum, maka dapat disimpulkan bahwa seluruh item pernyataan dianggap valid dan dapat digunakan Dallam penelitian ini.

Uji reliabiitas dilakukan terhadap item pernyataan yang dinyatakan valid.Uji ini digunakan untuk mengukur suatu kuesioner yang merupakan indikator dari variabel konstruk.Suatu kuesioner dikatakan reliable atau handal jika jawaban seseorang terhadap pernyataan adalah konsisten atau stabil dari waktu ke waktu. Suatu data dikatakan reliable jika Cronbach Alpha lebih besar dari 0,6. Semakin tinggi hasil yang diperoleh, maka berbanding lurus dengan realibilitasnya.

Hasil pengujian realibilitas kuesioner menghasilkan angka Cronbach's Alpha sebesar 0,709. Hal ini dapat dinyatakan bahwa semua pernyataan dari veriabel Pembiayaan Modal Kerja Dari Pemerintah (X1) teruji reliabilitasnya sehingga dinyatakan reliable.

Hasil pengujian realibilitas kuesioner menghasilkan angka Cronbach's Alpha sebesar 0,670.Hal ini dapat dinyatakan bahwa semua pernyataan dari veriabel Profesionalisme (X2) teruji reliabilitasnya sehingga dinyatakan reliable.

Hasil pengujian realibilitas kuesioner menghasilkan angka Cronbach's Alpha sebesar 0,823. Hal ini dapat menyatakan bahwa semua pernyataan dari Tingkat Pendapatan Usaha teruji relibilitasnya seingga dinyatakan reliable.

Uji normalitas bertujuan untuk menguji apakah model regresi, variaabel pengganggu atau residual berdistribusi normal. Uji normalitas ini dilakukan dengan uji statistic non-parametrik Kolmogrov-Smirnov (K-S) dengan ketentuan jika nilai signifikan (sig) > 0,05 maka data berdistribusi normal.

Berdasarkan hasil uji normalitas menunjukkan bahwa nilai Kolmogrov-Smirnov z sebesar 0,543 dan nilai signifikansi pada 0,929. Karena nilai signifikan $>0,05$ yaitu sebesar 0,543 maka dapat disimpulkan bahwa data berdistribusi normal dan asumsi normalitas terpenuhi.

Uji Multikolinieritas

Uji multikolinieritas bertujuan untuk menguji apakah regresi ditemukan adanya korelasi antar variabel bebas (independen). Multikolinieritas dapat diihat dari nilai tolerance dan lawannya, dan variance inflation factor (VIF). Nilai tolerance yang rendah sama dengan nilai VIF yang tinggi. Nilai Cutoff yang umum 
dipakai untuk menunjukkan adanya multikolinieritas. Multikolinieritas adalah nilai tolerance $<$ 0,10 maka dapat disimpilkan terbebas dari multikolinieritas dan jika nilai VIF < maka dapat disimpilkan tidak terkena gangguan multikolinieritas.

Hasil Uji Multikoinieritas, nilai tolerance dan VIF menunjukkan bahwa tidak ada satu variabel independen yang memiliki VIF lebih besar dari 10 dan tidak ada satu nilai tolerance variabel independen yang memenuhi nilai tolerance yaitu kurang dari 0,1 yang berarti tidak terjadi multikolinieritas.

Dari hasil tersebut, persamaan regresi dapat di peroleh dari standardized coefficients, hal ini karena pengukurannya menggunakan skala penilaian yang sama yaitu likert, sehingga persamaanya sebagai berikut:

$\mathrm{Y}=\alpha+\beta \mathrm{X}_{1}+\beta \mathrm{X}_{2}+\beta \mathrm{X}_{3}+\mathrm{e}$

$\mathrm{Y}=3.624+0,851+0,262+\mathrm{e}$

Keterangan:

$\mathrm{Y}=$ Tingkat Pendapatan Usaha

$\mathrm{X}_{1}=$ Pembiayaan Modal Kerja Dari Pemerintah

$\mathrm{X}_{2}=$ Profesionalisme

$\alpha=$ Konstanta

Persamaan regresi liniear berganda tersebut dijelaskan sebagai berikut:

a. Koefisien regresi $\left(\mathrm{X}_{1}\right)$ menyatakan bahwa variabel Pembiayaan Modal Kerja Dari Pemerintah bertanda positif dan signifikan terhadap Tingkat Pendapatan Usaha.

b. Koefisien regresi $\left(\mathrm{X}_{2}\right)$ menyatakan bahwa variabel Profesionalisme bertanda positif dan signifikan terhadap Tingkt Pendapatan Usaha.

\section{Penutup}

Berdasarkan hasil penelitian, maka kesimpulan yang didapat dari penelitian ini mengenai pengaruh Pembiayaan Modal Kerja dari Pemerintah dan Profesionalisme terhadap Tingkat Pendapatan Usaha para pengrajin usaha mikro kerupuk udang di Kelurahan Teluk Nilau yaitu Pembiayaan Modal Kerja Dari Pemerintah berpengaruh secara signifikan terhadap Tingkat Pendapatan Usaha sebesar 4,637\% dan Profesionalisme juga berpengaruh secara signifikan terhadap Tingkat Pendapatan Usaha sebesar 3,018\%. Variabel Pembiayaan Modal Kerja Dari Pemerintah lebih unggul dibandingkan variabel Profesionalisme atau dengan kata lain variabel Pembiayaan Modal Kerja Dari Pemerintah memiliki pengaruh yang lebih tinggi terhadap Tingkat Pendapatan Usaha dengan persentase 4,637\% dibandingkan dengan variabel Profesionalisme yang hanya memiliki persentase sebesar 3,018\%. 


\section{BIBLIOGRAFI}

Adiwarman A. Karim, Bank Islam: Analisis Fiqih dan Keuangan, Jakarta: Rajagrafindo Persada, 2013.

Agus Tri Basuki dan Nano Prawoto, Analisis Regresi dalam Penelitian Ekonomi \& Bisnis (Dilengkapi Aplikasi Spss \& Eviews), Jakarta: Raja GrafindoPersada.

Arikunto. S, Prosedur Penelitian Suatu Pendekatan Praktik, Jakarta: Rineka Cipta,2006.

BN. Marbun, Kamus Manajemen, Jakarta : Pustaka Sinar Harapan, 2003.

Danang Sunyoto, Metode Penelitian Akuntansi, Bandung: Refika Aditama, 2013.

Husaini Usman dan Purnomo Setiady Akbar, Pengantar Statistika, Jakarta : Bumi Aksara, Edisi Kedua, 2006.

Kasmir, Analisis Laporan Keuangan, Jakarta : Raja grafindo Persada, 2012.

Kasmir, Bank dan Lembaga Keuangan Lainnya, jakarta: Raja grafindo Persada,2002.

Kasmir, Manajemen Sumber Daya Manusia (Teori Dan Praktik), Jakarta: Raja grafindo Persada 2016.

M. Fuad dkk, Pengantar Bisnis, Jakarta :Gramedia Pustaka Umum, 2006.

Ratna Sukmayan, Ilmu Pengetahuan Sosial, Jakarta: Galaxy Puspa Mega, 2008.

Sadono Sukrisno, Teori Pengantar Mikro Ekonomi, Jakarta :Raja grafindo Persada, 2006.

Syafi'I Antonio, Bank Syariah: Dari Teori KePraktis, Jakarta: Gema Insani, 2001.

Tim Penyusun, Pedoman Penulisan Skripsi, Jambi: Syariah Press Fakultas Syariah IAIN Sulthan Thaha Saifuddin Jambi, Cet. Pertama, 2010.

Wilson Bangun, Manajemen Sumber Daya Manusia ,Penerbit: Erlangga, 2012.

Abd Wahid, Al-Qur'an Sumber Peradaban, Jurnal Ushuluddin, Vol. XVIII, No. 2, Juli 2012.

Adinda Nurrizki, Pengaruh Pembiayaan Modal Kerja Terhadap Tingkat Pendapatan Mitra Koperasi Jasa Keuangan Syariah (KJKS) Ibu Mandiri Serpong, Skripsi Universitas Syarif Hidayatullah Jakarta, Fakultas Ilmu Dakwah Dan Ilmu Komunikasi, Program Studi Manajemen Dakwah, 2014.

D.K.R. Ardiana, I.A. Brahmayanti, Subaedi, Jurnal Manajemen dan Kewirausahaan, Vol.12, No. 1, BulanMaret. Tahun. 2010.

Merisa Fajar Aisyah. Pengaruh Kualitas Sumber Daya Manusia, Profesionalisme Kerja, dan Komitmen Terhadap Kinerja Karyawan Pada PDAM Kabupaten Jember, Skripsi Universitas Jember, Fakultas Ekonomi, Jurusan Manajemen, 2015. 